www.pieb.cz

\section{THE EFFICIENCY OF PUBLIC SERVICE OBLIGATION FOR FOOD SUBSIDY IN INDONESIA: REVIEW OF COST STRUCTURE ANALYSIS}

\author{
IRWAN TRINUGROHO, \\ SUTOMO, \\ ASRI LAKSMI RIANI \\ Faculty of Economics \\ Sebelas Maret University, Indonesia
}

JEL Classifications: $\mathrm{H} 21$

Key words: Food subsidy, efficiency, cost structure, Indonesia.

Abstract: The paper reviews the efficiency of food subsidy in Indonesia based on cost structure analysis. Using the comparison between cost of good of government and cost of good of National Logistics Board appointed to manage and channel the subsidy. The level of efficiency has decreased in the recent years because of increase in costs of exploitation, management cost and interest expense. It is suggested that government has to determine the cut-off point as a feasibility assessment of cost of subsidy.

ISSN: 1804-0527 (online) 1804-0519 (print) $\quad$ Vol.7(1), PP. 45-47

\section{Introduction}

Food subsidy policy has been implemented in many developing countries, but often lead to criticism because it causes the government's budget deficit. However, food subsidy policy advocates that the program is necessary to ensure fulfillment of basic food for the poor because poor people spend a large proportion of their income just to meet their food needs. With the food subsidy it can be expected that the most of revenue not only used for food consumption but also for non-food consumption and for working capital; so such change will ultimately drive economic growth (Adams, 2007; Ragbendra et.al, 2009).

Indonesia's food subsidy policy, called as RASKIN, has been implemented since 1999 and is a continuation of the Special Market Operations Program implemented starting July 1998. RASKIN program is a national program aimed at helping poor households to meet food needs and reducing the adequacy of the financial burden by providing subsidized rice. To implement RASKIN program, the government appointed Perum BULOG (National Logistics Board) in accordance with Government Regulation No.7/2003. In accordance with this directive, Perum BULOG must: (1) to organize a business staple food logistics that adequate and have quality for many people; (2) perform, in certain cases, specified by the government tasks on securing basic food prices, managing food stock, and distributing the staple food to certain segments of society, particularly the rice and other staple foods in the framework of food security. Another legal institution regulating the assignment to the state-owned enterprise to channel the subsidy is Law of the Republic of Indonesia No. 19/2003, article 66 paragraph 1 states that: "The government can give a special assignment to the state-owned enterprise to perform the functions of public benefit by taking into account the intent and purpose of state activity". If such assignment according to examination financially inflexible, the government must provide compensation for all costs incurred plus the expected margin is called a subsidy.

Based on yearly data from the Ministry of Finance, the amount of food subsidies (RASKIN) tends to always go up. This is caused due to an increasing of purchasing price (procurement) and also because of increasing of the number of target poor families (poor households). Meanwhile, food subsidies seen as the percentage of gross domestic income (GDP) are more fluctuated and do not follow the increasing trend. Obviously, this occurs as there is something specific in each fiscal year. In 2005 GDP growth was relatively low due to policy to increase fuel price; therefore, the food subsidy ratio to GDP was relatively high even if the amount of food subsidy was not increasing significantly. Although the number of target families increased in 2006 and 2007, the percentage of food subsidies to GDP decreased due to the reduction in the allocation of rice per month/ family. Later in 2008, the proportion of food subsidies to GDP increased again due to the addition of the target poor families by maintaining the total allocation of rice. More detail can be seen in Figures 1 and 2.

\section{Food subsidy allocation in Indonesia}

Subsidies are payment by the government to companies and households to achieve specific goals that enable them to produce or consume a product in greater quantity or at a cheaper price (Spencer and Amos, 1993). There are two principal methods of subsidy as fiscal instruments:

(1) Producer subsidy is done by lowering the production cost of producer, or by increasing price received by producers;

(2) Consumer subsidy is done by lowering the price paid by consumers for a product.

Food subsidy programs in Indonesia (RASKIN) use a consumer subsidy, because the ultimate goal of this program is to make cheaper prices paid by consumers for the consumption of rice. As in most other developing countries, the main problem of food subsidy policy in Indonesia is a trade-off between fiscal needs (food subsidies as fiscal instruments) and fiscal constraints (government budget constraints). On the one hand, food subsidy is a governmental obligation to guarantee the availability of staple food at a price affordable by the poor people. On the other hand, the government is faced with the constraints of fiscal limitations. Therefore, to ensure fiscal sustainability, it is necessary to manage properly the implementation of food subsidy programs, so that programs can run optimally in terms of target effectiveness and budget efficiency. 
FIGURE 1. FOOD SUBSIDY (in Billion Rupiah)

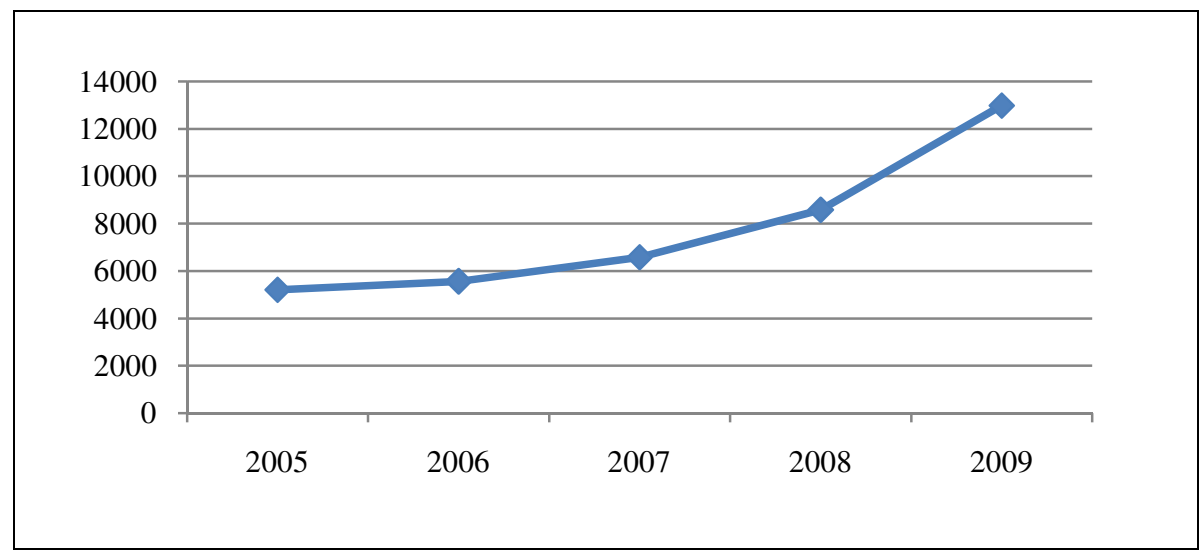

FiguRE 2. PERCENTAGE OF FOOD SUBSIDY TO GDP

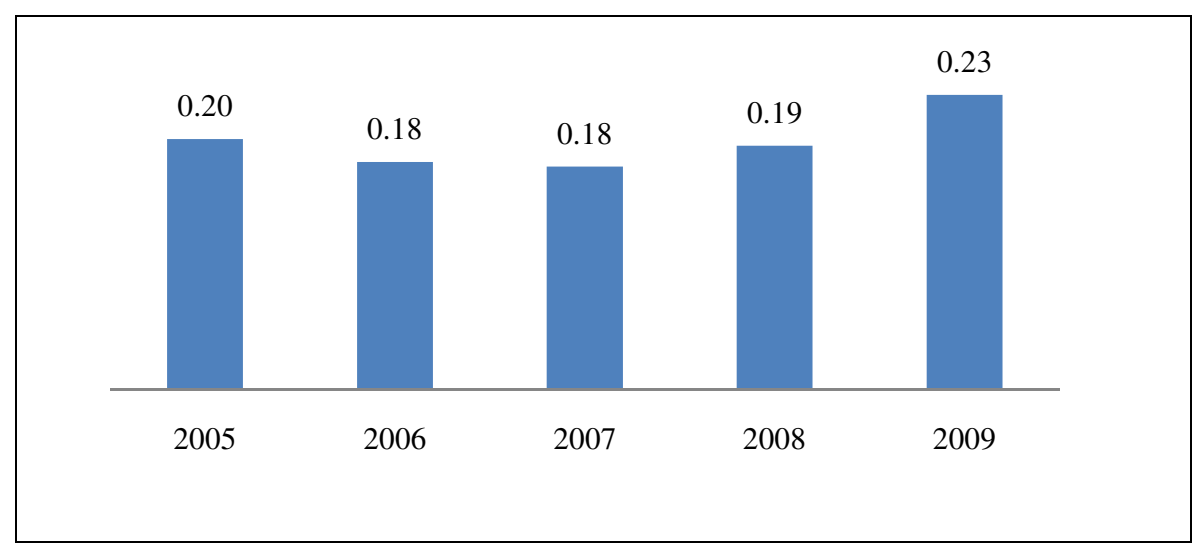

TABLE 1. CALCULATION OF COST EFFICIENCY

\begin{tabular}{lcccccccc}
\hline Components & \multicolumn{7}{c}{ Year } \\
\cline { 2 - 9 } & 2002 & 2003 & 2004 & 2005 & 2006 & 2007 & 2008 & 2009 \\
\hline HPP $(\mathrm{Rp} / \mathrm{kg})$ & 2470 & 2790 & 2790 & 2805 & 3550 & 4000 & 4300 & 4300 \\
\hline HPB $(\mathrm{Rp} / \mathrm{kg})$ & 2804 & 3343 & 3343 & 3494 & 4275 & 4619 & 5200 & 5500 \\
\hline Cost efficiency & 0.8809 & 0.8346 & 0.8346 & 0.8028 & 0.8304 & 0.8660 & 0.8270 & 0.7818 \\
\hline
\end{tabular}

Method of food subsidy calculation used in Indonesia is as follows:

$$
D \times S \times A \times(H P B-H J R)
$$

Where: $D$ - duration of RASKIN (months); $S$ - number of target poor families (households); $A$ - allocation of rice per month / $\mathrm{HH}(\mathrm{kg}) ; H P B$ - rice purchase price by the government to BULOG (Rupiah (Rp) / kg); HJR - selling price to poor households (Rupiah (Rp) / $\mathrm{kg}$ ), it is set in a certain price by the government.

\section{Efficiency measurement}

The cost structure is the structure of costs that were incurred during processing raw materials and other components into the output. In other words the overall cost structure represents costs incurred to form a finished product. Related to the assignment of government to BULOG in food subsidy in Indonesia, the overall cost structure components are all of cost in the $H P B$. To see how efficient method of calculating the subsidy, we analyze the cost of components in $H P B . H P B$ is calculated using the following method:

\section{$H P B=($ Initial Credit Outstanding + Procurement} Costs before Interest + Total Interest-Value of Inventory in end period) / Volume Distribution

Here, Initial Credit Outstanding = bank loan to fund the initial distribution $=$ initial stock $\mathrm{x}$ HPB previous year.

Procurement Costs before interest represents the purchase price to the farmers $(H P P)$, the cost of procurement, exploitation costs (warehouse rental fees, processing costs, distribution costs), cost of packing bags, cost of management (personnel costs, costs of goods expenditures, operating costs), research costs and margins. 
Value of Inventory is the volume of rice that is reserved for storage at the end of the current year $\mathrm{x} H P B$.

Volume of Distribution - quantity of rice entitled to be distributed in the current year.

The main components of $H P B$ include $H P P$, the purchase price of rice by BULOG to farmers or in accounting terms is the cost of goods sold. Simply put, to assess whether the cost is efficient or not, we calculate cost efficiency which is the ratio between the HPP against $H P B$; the higher the cost efficiency is, the more efficient the cost structure becomes. Based on data from the Ministry of Finance, the average ratio for 2002-2009 amounted to $83.22 \%$, it means that $16.18 \%$ of the $H P B$ is a cost and margin excluding the cost of goods. In the past three years, the ratio of $H P P$ to $H P B$ has decreased, in the 2009 the ratio has made $78.18 \%$, the lowest one since 2002 (see Table 1). This indicates an increase in the proportion of costs and margins outside the $H P P$, which means a decline in cost efficiency. The research of SMERU Institute (2007) noted that there is an increase in component costs of exploitation, management cost and interest expense during the period 2002 to 2007, while procurement and packaging costs fluctuate.

\section{Conclusion}

Our review of the cost structure of food subsidy in Indonesia concludes that the cost structure is relatively inefficient. In average $16.88 \%$ of cost of subsidy during five years was not covered by the base price $(H P P)$, and the cost efficiency rate has decreased. We suggest that the government should seek for the cut-off point as a feasibility assessment. We also suggest that the government and BULOG should employ stress testing analysis to see the sensitivity of food subsidy expenditure in case of fluctuations/changes in factors affecting.

\section{References}

Government Regulation of the Republic of Indonesia, 2003. On Establishment of Perum (State-Owned Company) BULOG (State Logistics Agency), No.7/2003.

Law of the Republic of Indonesia, 2003. On State-owned Enterprise (BUMN),No.19/2003.

Raghbendra, J., Katsushi, S., Raghav, G., 2009. "Poverty, undernutrition and vulnerability in rural India: Public works versus food subsidy," Working paper, No.135, Chronic Poverty Research Centre.

RH Adams, Jr., 2007. "Self-targeted subsidies: the distributional impact of the Egyptian food subsidy system," Working paper, World Bank

SMERU Research Institute. 2007. Efektivitas Pelaksanaan Raskin [The Effectiveness of Raskin], Research Report.

Spencer, M., Amos, O., 1993. Contemporary Economics 8th edition, Worth Publishers, New York. 